\title{
The effect of aqueous extract of Marticaria Chamomilla flowers on some physiological properties in broiler chickens.
}

\author{
S. A. H. AL-Moramadhi \\ Coll. of Vet. Med./ Univ of AL-Qadissiya
}

\begin{abstract}
This study was conducted on broiler chickens to investigate the effect of Marticaria chamomilla flowers extract on some physiological properties. One day age Fawbro birds (Average weight $55 \mathrm{~g}$ ) were used in this study, they fed ad libtum until 7weeks age. (60 chickes) were divided into three groups (each group has 20 birds ).

1-treatment one: administrated orally the aqueous extract of Marticaria chamomilla flowers at concentration $50 \mathrm{mg} / \mathrm{kg}$ body weight .

2-treatment two: administrated orally the aqueous extract of Marticaria chamomilla flowers at concentration $100 \mathrm{mg} / \mathrm{kg}$ body weight

3-control group: administrated distilled water .At the end of experiment blood samples were taken from brachial vein for ten birds of each group for hematological and bio chemical examination ,the following parameters are used:- serum glucose concentration, serum cholesterol concentration ,hemoglobin concentration ,packed cell volume, body weight and food intake. Results showed significant decrease $(\mathrm{p}<0.05)$ in glucose concentration in treatments groups compared with control, and significant decrease $(\mathrm{p}<0.05)$ in cholesterol concentration in treatments groups compared with the control. While there was no significant effect on hemoglobin concentration, packed cell volume, body weight and food intake in treatments groups compared with the control.
\end{abstract}

\section{Introduction}

Chamomile is a daisy like, applescented flower that has used medicinally for thousands in human (12).Chamomile, Marticaria chamomilla, widely used through the world .its primary used is as sedative anxiolytic and antispasmodic. The use of chamomile comes from two Greek world meaning "ground apple" for its apple like smell (15).Chamomile main active constituents are chamazulene, apigenin and bisabolol.the proazulenes in the herb produce chamazulene on steam distillation which markedly antiallergenic (9).Due to its antispasmodic properties chamomile is a good remedy for all cramping pains especially for an abdominal cramping in children at the same time it has a carminative effect of relieving flatulence (10). In pediatric medicine chamomile is used as tea or syrup (2). it can be taken as a herbal tea . one of the active ingredients of the essential oil from chamomile is the terpene and bisabolol, and other active ingredients include farnesene, chamazulene, flavonoids (including apigenin, quercetin, patuletin and luteolin and coumarin.(16) A review of the medical literature reported a number of beneficial effects for chamomile in vitro and animal tests. Research with animals suggests antispasmodic anxiolytic, antiinflammatory and some anti-mutagenic and cholesterol-lowering effects for chamomile. It also showed some benefit in an animal model of diabetes ((8) .In vitro chamomile has demonstrated moderate antimicrobial and antioxidant properties and significant anti platelet activity (14).

\section{Materials and Methods}

Animals :- 60 birds (Fawbro) were used and reared ad libtum from one day age until 7 weeks of age, the birds divided into 3 groups at age one week. 1-treatment 1: have 20 bids administered the aqueous extract of Marticaria chamomilla at concentration $50 \mathrm{mg} / \mathrm{kg}$. 
2- Treatment 2: have 20 birds administered the aqueous extract of Marticaria chamomilla at concentration $100 \mathrm{mg} / \mathrm{kg}$.
3- Control: have 20 birds administered distilled water.

((Composition of ration in broilers))

\begin{tabular}{|c|c|c|}
\hline Substances & Starter ration percentage & Finisher ration percentage \\
\hline Corn & 56.6 & 54 \\
\hline Wheat & 18 & 20 \\
\hline Soyben meal & 13.4 & 5 \\
\hline Concentrated protein & 10 & 0.7 \\
\hline Calcium and phosphorus & 0.7 & 0.5 \\
\hline Limestone & 0.5 & 0.5 \\
\hline Methionin & 0.5 & 0.3 \\
\hline Salt & 0.3 & 2900 \\
\hline Metabolic energy & 3010 & 20.07 \\
\hline Crude protein & 22.04 & 59 \\
\hline
\end{tabular}

Chemicals :- Cholesterol kit form SpinReact laboratories Ltd. Glucose kit from spin React laboratories Ltd, distilled water and hemoglobin kit from Randox laboratories Ltd.

Plant :- chamomile flowers obtained from herbalists, cleaned and powdered then extracted according to Harbornes'method (6). Different concentrations are prepared $50 \mathrm{mg} / \mathrm{kg}, 100 \mathrm{mg} / \mathrm{kg}$.

Instruments: - spectrophotometer, hematocritcentrifuge.

Blood samples: blood samples were taken from brachial vein for ten birds from each groups and put in test tubes containing anticoagulant (EDTA) for hematological analysis and in test tubes without anticoagulants to prepare serum for biochemical analysis.

Tests: cholesterol levels were measured according to Kaplan method $(7,11)$ hemoglobin concentration and packed cell volumes are measured according to Cole's method (4).

Food intake: Weekly food intakes are measured for each group. Food intake $(\mathrm{g})=$ quantity of total given food- quantity of remained food.

Body weight: Weekly body weights are measured for each group

Statistical analysis: - Data analyzed using F-test and Least Significant Differences (LSD) between Means. (1). 


\section{Results}

1-glucose concentration: there is concentration in treatments groups significant decrease $(\mathrm{p}<0.05)$ in glucose compared with the control table -1 -

Table -1- the effect of marticaria chamomilla extract on blood glucose concentration in broiler chickens.

\begin{tabular}{|c|c|}
\hline groups & Glucose concentration in mg /dl \\
\hline Treatment1 & $182 \pm 3.15 \mathrm{~b}$ \\
\hline Treatment2 & $163 \pm 2.95 \mathrm{~b}$ \\
\hline control & $211.25 \pm 2.25 \mathrm{a}$ \\
\hline
\end{tabular}

-the values are mean \pm standard error.

-the different letters indicate significant differences $(p<0.05)$ between groups.

-similar letters indicate no significant difference between groups.

2-Cholesterol concentration: there is significant decrease $(\mathrm{p}<0.05)$ in cholesterol

concentration in treatments groups compared with control. Table(2)

Table (2)the effect of marticaria chamomilla flowers aqueous extract on cholesterol concentration in broiler chickens

\begin{tabular}{|c|c|}
\hline Groups & Cholesterol concentration mg /dl \\
\hline Treatment 1 & $130.75 \pm 5.5 \mathrm{a}$ \\
\hline Treatment 2 & $121 \pm 5.25 \mathrm{a}$ \\
\hline & $154.25 \pm 6.1 \mathrm{~b}$ \\
\hline
\end{tabular}

-values are means \pm SEM

-the different letters indicate significant differences $(p<0.05)$ between groups.

- similar letters indicate no significant differences between groups.

3-Hemoglobin concentration:- the data indicate no significant effect of marticaria chamomilla extract on hemoglobin concentration .table (3) 
Table (3) the effect of marticaria chamomilla extract on hemoglobin concentration in broiler chickens

-Values are means \pm SEM

\begin{tabular}{|c|c|}
\hline Groups & Hb concentration $\mathrm{mg} / \mathrm{dl}$ \\
\hline Treatment 1 & $12.25 \pm 0.62 \mathrm{a}$ \\
\hline Treatment 2 & $13.5 \pm 0.28 \mathrm{a}$ \\
\hline Control & $12.75 \pm 0.47 \mathrm{a}$ \\
\hline
\end{tabular}

-the similar letters indicate no significant differences between groups.

4-packed cell volume: the data indicate no significant effect of marticaria chamomilla extract on packed cell volume in broiler chickens. Table(4)

Table (4) the effect of marticaria chamomilla extract on packed cell volume in broiler chickens

marticaria chamomilla extract on packed
\begin{tabular}{|c|c|}
\hline chickens \\
\hline Troups & Packed cell volume $\%$ \\
\hline Treatment 2 & $29 \pm 0.76 \mathrm{a}$ \\
\hline Control & $32 \pm 1 \mathrm{a}$ \\
\hline
\end{tabular}

-Values are means+ SEM-

-the similar letters indicate no significant differences between groups.

5-Food intake: the data showed no significant effect of marticaria chamomilla extract on food intake in broiler chickens. Table(5).

Table(5) the effect of Marticaria chamomilla extract on food intake in broiler chickens.

-the values are means + SEM-

\begin{tabular}{|c|l|l|l|}
\hline \multirow{2}{*}{ Age in weeks } & \multicolumn{3}{l}{ Food intake in grams } \\
\cline { 2 - 4 } & Treatment 1 & Treatment 2 & Control 3 \\
\hline Week 2 & $205 \pm 6.8 \mathrm{a}$ & $199 \pm 7 \mathrm{a}$ & $192 \pm 6.5 \mathrm{a}$ \\
\hline Week 3 & $232.8 \pm 4.5 \mathrm{a}$ & $280 \pm 5 \mathrm{a}$ & $306 \pm 5.2 \mathrm{a}$ \\
\hline Week 4 & $499 \pm 3.4 \mathrm{a}$ & $452 \pm 4 \mathrm{a}$ & $530 \pm 4.32 \mathrm{a}$ \\
\hline Week 5 & $468 \pm 5.5 \mathrm{a}$ & $408 \pm 6.1 \mathrm{a}$ & $404 \pm 6.8 \mathrm{a}$ \\
\hline Week 6 & $543 \pm 3.3 \mathrm{a}$ & $629 \pm 4.25 \mathrm{a}$ & $520 \pm 4.3 \mathrm{a}$ \\
\hline Week 7 & $715 \pm 404 \mathrm{a}$ & $687 \pm 4.2 \mathrm{a}$ & $688.6 \pm 5 \mathrm{a}$ \\
\hline
\end{tabular}

-the similar letters showed no significant differences between groups. 
6-Body weight:- Data indicated no significant effect of marticaria chamomilla aqueous extract on body weight in broiler chickens. Table(6).

Table (6) the effect of Marticaria chamomilla extract on body weight in broiler chickens

- Values are means \pm SEM

\begin{tabular}{|c|c|c|c|}
\hline Age in weeks & \multicolumn{3}{|c|}{ Body weight( g) } \\
\hline & Treatment 1 & Treatment 2 & Control 3 \\
\hline Week 2 & $123.2 \pm 1.68 \mathrm{a}$ & $120.8 \pm 2.38 \mathrm{a}$ & $112.21 .68 \mathrm{a}$ \\
\hline Week 3 & $210.4 \pm 5.34 \mathrm{a}$ & $213.2 \pm 5.5 \mathrm{a}$ & $208 \pm 6.26 \mathrm{a}$ \\
\hline Week 4 & $311.6 \pm 5 \mathrm{a}$ & $373 \pm 6.6 \mathrm{a}$ & $316 \pm 8.8 \mathrm{a}$ \\
\hline Week 5 & $561 \pm 2.2 \mathrm{a}$ & $577.6 \pm 1.4 \mathrm{a}$ & $555 \pm 1 \mathrm{a}$ \\
\hline Week 6 & $888.2 \pm 3.5 \mathrm{a}$ & $782.2 \pm 2.5 \mathrm{a}$ & $845.8 \pm 3 \mathrm{a}$ \\
\hline Week 7 & $1103 \pm 5.1 \mathrm{a}$ & $1131.6 \pm 5.4 \mathrm{a}$ & $1169.8 \pm 5.4 \mathrm{a}$ \\
\hline
\end{tabular}

-similar letters indicated no significant differences between groups.

\section{Discussion}

1-Glucose concentration: the results showed significant decrease in glucose concentration in treatments groups. (Concentrations of chamomile extracts $50 \mathrm{mg} / \mathrm{kg}, \quad 100 \mathrm{mg} / \mathrm{kg}$ respectively) compared with the control. This effect was due to antihyperglycemic effect of Marticaria chamomilla extract, the mechanisms of blood glucose lowering activity may be to stimulation of peripheral glucose utilization especially in muscle and adipose tissue and/or the restoration of enzyme activity which play apart in the glucose and glycogen metabolism, this accept with results of researchers, they found that full hot water extract of chamomile possessed inhibitory activity of sucrase enzymes, which are responsible for the conversion of sucrose to fructose and glucose; inhibition would reduce the rise in glucose levels(8).Another study demonstrated that daily consumption of chamomile tea with meals could be Potentially useful in the prevention and self-medication of hyperglycemia and diabetic complications (10).

2-Cholesterol concentration:- the results showed significant decrease in cholesterol concentration in treatments groups, compared with control this decrease in cholesterol concentrations is due to antioxidants properties of Marticaria chamomilla extract. In a study researchers found that the ethanolic extract of Marticaria chamomilla inhibit the formation of free radicals and may scavenge the reactive oxygen metabolites through various antioxidants compounds in them (3).In another study in vivo, they found that chamazulen, the active ingredient in Marticaria chamomilla, effect free radical processes and inhibit lipid peroxidation (4).

In vitro data: Chamazulene affects free radical processes and inhibits lipid peroxidation

in a concentration- and time-dependent manner(14).

3-Hemoglobin concentration and packed cell volume:-the results showed no significant effect of Marticaria chamomilla extract on hemoglobin concentration and packed cell volume. It may be has No effect on red blood cell proliferation and circulation. 
4-Food intake and body weight: - the results showed no significant effect of Marticaria chamomilla extract on body weight. This is due to limited effect of chamomile components on fat storage, in study researchers found limited effect of

\section{References}

ointment on acute radiation skin reaction. Acta .oncology. 30:375396.

10. Mckay, D.L.and Blumberg, J.B. (2006).A review of the bioactivity and potential health benefits of chamomile tea Phototherapy Res.20:519-530.

11. Naito, H. K. (1984). Clinical Chemistry . Kaplan, A. Mosby Co S.Louis Toronto pp; 1194-1206.

12. Ohara, M.A., Kiefer, D., Farrell, K. and Kamper, K. (1998). Review of 12 commonly used medicinal herbs. Arch. Fam. Med. 7: 523536.

13. Poracova ,J. ahatnanska, ; Blascakova, ;Taylorova, B.; Sutiakova, I;Tanishima, K.; Takabayashi,H and Cheng, B.J.(2009).Effect of chamomile essential oil on eggs production and weight of laying hens hisex braun. Iishs Acta Horticulture 749-1

14. Rekka, E.A.; kourounakis, A. P.and Kourounakis, P.N. (1996). Investigation of the effect of chamazulene on lipid peroxidation and free radical processes. Research communications in Molecular Pathology and Pharmacolog.92:361-364.

15. Szelenyi, I Isaac,O. and Theimer, K. (1979).

Pharmacological experiments with chamomile: Experimental studies of the ulcer protectective effect of chamomile. Plant. Med. 35:218-227

16. Tyler V.E. (1996).What pharmacists should know about herbal remedies?J. Am. Pharm Assoc. 36:29-37. chamomile oil on weight of laying hens (13).the results showed no significant effect of Marticaria chamomilla extract on food intake, it may be to limited effect of chamomile extract on appetite.

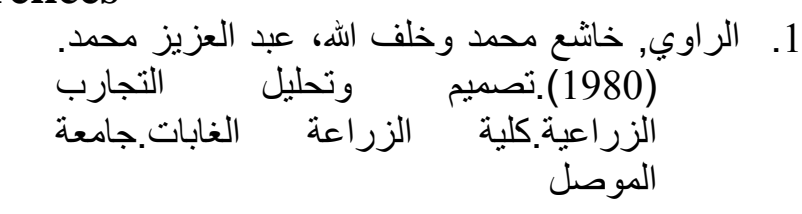

2. Blumenthal, M. Gruen Wald, J., Hall, T.,Riggines, c.and Rister,R. (1998). Medicinal plants for Human use. German commissionE monographs: Medicinal plants for Human use Austin, Tex: American Council

3. Cemek, M., kaga, S. , Sim Seek, N., Emin , M. and konak , M (2007). Antihyperglycemic and ant oxidative potential of Marticaria chamomilla $\mathrm{L}$ in streptozotocin induced diabetic J. Nat .Med.3:228235.

4. Coles, E. H. (1986).Veterinary Clinical Pathology. $4^{\text {th }} \quad$ ed.W.B.Saunders. London.

5. Fiddler, p.,lorinzi, C.and Fallon, J. (1996).Prospective evolutions of chamomile mouth wash for the prevention of fu-induced oral mucositis Can Cer. 77:523-525.

6. Harborne, J.D.; Mabray, T.J. and Mabray, H. (1975). Physiology and Function of Flavonoid. The flavoid . Acade. press . New York. San Francisco. p: 970-1042.

7. Kaplan, L.A. (1984). Clinical Chemistry . Mosby. CO.St, Lou, Toronto. Pp; 1032-1036.

8. kato A., Mnoshima Y. Yamamoto, J., Adachi, I.,Watson, A.A. and Nash, R.J. (2007).Protective effects of dietary chamomile tea on diabetic complications. Journal of Agriculture and food chemistry 56:8206-8211.

9. Maiche, A, Grohn, P. and MakiHokkonen, H(1991). Effect of chamomile cream and almond 


\title{
تأثير المستخلص المائي لأزهار البابونج في بعض الصفات الفسلجية في فروج اللحم
}

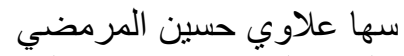 \\ كلية الطب البيطري / جامعة القادسية المردية
}

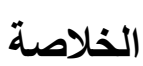

أجريت هذه الدراسة على أفر اخ فروج اللحم نوع فاوبرو لمعرفة تأثير المستخلص المائي لأزهار البابونج في

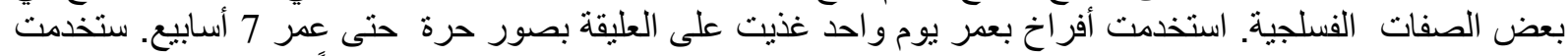

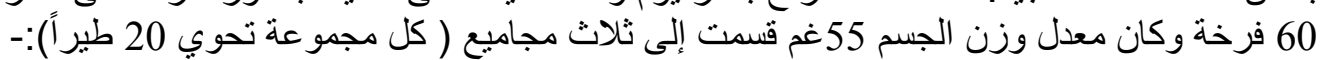

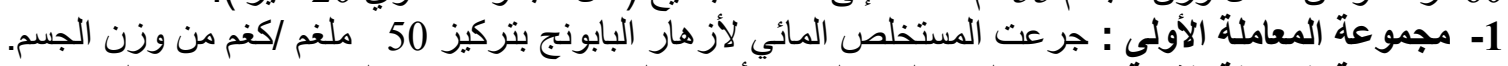

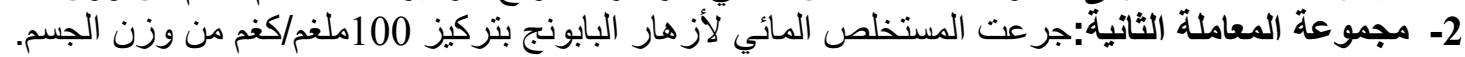

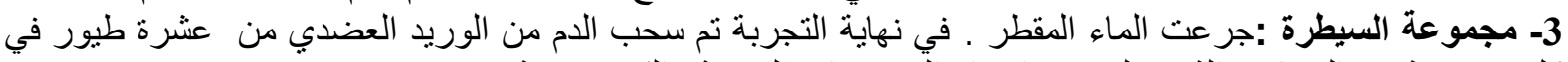

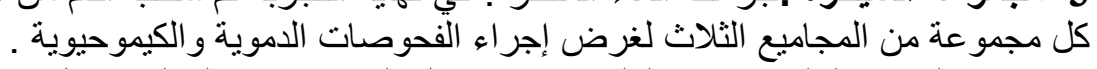

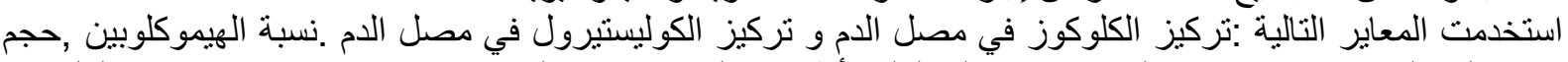

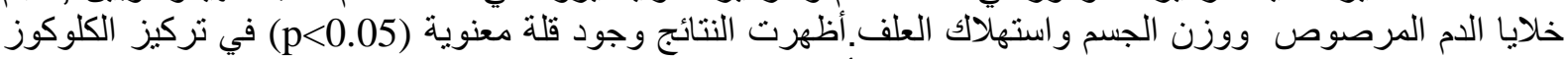

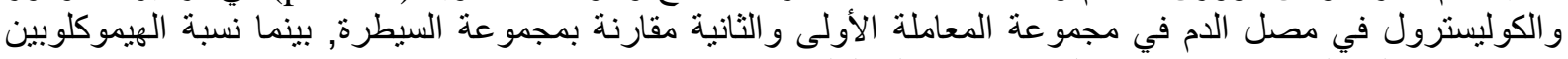
وحجم خلايا الدم المرصوص وروزن الجسم و استهلاك العلف. 